\title{
Sacred and secular aspects of Phoenicians' life at Motya (Sicily, Italy) inferred by multidisciplinary archaeobotanical analyses
}

\author{
Claudia Moricca $(1,2)$
}

(1) Department of Earth Sciences, Sapienza University of Rome, Piazzale Aldo Moro 5, 00185 Rome, Italy.

(2) Department of Environmental Biology, Sapienza University of Rome, Piazzale Aldo Moro 5, 00185 Rome, Italy.

Corresponding author e-mail: claudia.moricca@uniroma1.it

Document type: Short note.

Manuscript received 06 April 2021; accepted 29 May 2021; published online 14 June 2021; editorial responsibility and handling by M. Pantaloni.

\section{ABSTRACT}

The present study focuses on archaeobotanical analyses performed at the Phoenicians site of Motya, a small island (ca. 45 ha) located in the Stagnone di Marsala, in western Sicily.

The study of macro-remains focused on two closed contexts: a votive favissa by the sacred area of "Cappiddazzu", and a disposal pit in Area D, both dating between the $8^{\text {th }}$ and the $6^{\text {th }}$ century BC. In the latter context, palynological analyses were also performed. The study allows to reconstruct sacred and secular aspects of humanenvironment interactions of Phoenicians at Motya, also providing information regarding past environment. Concerning the ritual sphere, ceremonial meals likely accompanied animal sacrifices. Food and flower offerings are also attested. Interesting is the finding of officinal plants and plants toxic to livestock. From the secular perspective, information was gathered on human diet, crop processing, import products and land exploitation. Finally, a combination of palynology and anthracology has allowed to describe the environment and highlight changes that occurred with time.

KEYWORDS: archaeobotany, Phoenicians, paleodiet, paleoenvironment, anthracology.

\section{INTRODUCTION}

Phoenicians are a multifaceted culture native of the Levant, which spread across the Mediterranean during the $2^{\text {nd }}$ and $1^{\text {st }}$ millennia BC. Their spread towards the west involved major islands (e.g. Crete, Sicily, and Sardinia) and mainland coastal areas, including Southern Iberia and Northern Africa (Nigro, 2019).

Although a lot is now known about them and is still being learnt through archaeological excavations, Phoenicians' relationship with plants and the environment that surrounded them is still under-explored. The present study aims to contribute to the knowledge of these interactions by focusing on the archaeological site of Motya (Fig. 1). It is a small island (ca. 45 ha) found in Western Sicily, in the Marsala lagoon, between the present-day cities of Trapani and Marsala. Due to its strategic setting in the middle of the Mediterranean, its harbored position within a lagoon and the presence of fresh-water sources, the site was chosen as a settlement by Phoenicians in the $8^{\text {th }}$ century BC and was occupied by them until the siege of Motya in 397 BC (Nigro \& Spagnoli, 2017).
The "Missione Archeologica a Mozia" of Sapienza University has been responsible for excavations on the island since 1964, under the leadership of Prof. Lorenzo Nigro starting from 2002. Excavations at Motya are characterized by a high degree of multidisciplinarity, including studies in the field of archaeozoology (Alhaique, 2012), petrography (Fabrizi et al., 2020) and metallurgical techniques (Bernabale et al., 2019). However, the only (preliminary) archaeobotanical analyses concerned cores from the submerged street connecting the islet to the mainland (Terranova et al., 2009). A recent addition is constituted by the analysis of dental calculus of the inhabitants of Motya, where some starch granules, pollen grains and plant trichomes were found (D'Agostino et al., 2020).

In the past couple of years, the scenario has changed following the publication of papers focused on archaeobotanical remains (Moricca et al., 2020; Moricca et al., 2021a; Moricca et al., 2021b). In this study these results will be summarized and considered together for the first time, allowing to combine studies of macro- and microremains performed on sacred and secular contexts, thus depicting a broad image of human-plant interactions of Phoenicians at Motya.

\section{MATERIALS AND METHODS}

Published data are taken in consideration in the present study. Archaeobotanical analyses so far performed at Motya focused on three closed contexts (Fig. 2). The first one is represented by a votive pit (also called a favissa; F.7057) adjacent to the Temple of Melqart/Herakles, found in the "Cappiddazzu" area, where the remains of at least seven articulated bovines were found, along with a smaller pit (F.7012), also interpreted as being connected to ritual practices (Moricca et al., 2020). For the purpose of this study, these "sacred" contexts will be considered here as a whole. The other context thoroughly analysed is a disposal pit (F.1112) found in Area D, where the first Phoenician settlement is believed to have been found (Moricca et al., 2021a). Here, four filling layers were identified. Based on ceramic evidence, both contexts are roughly ascribed 


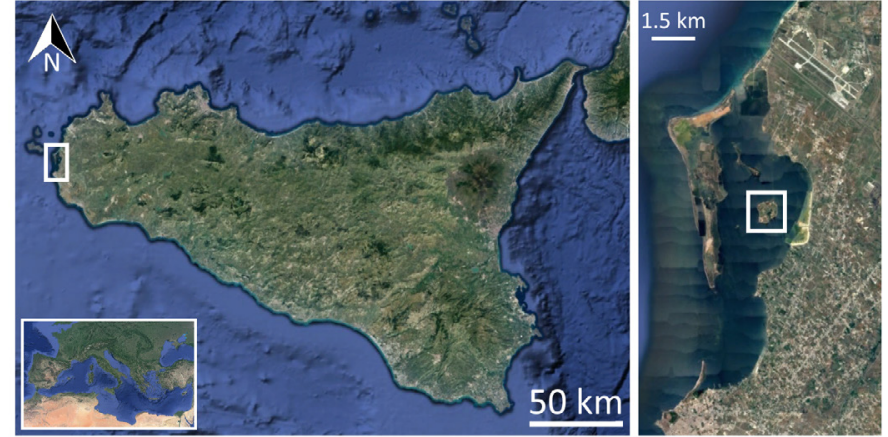

Fig. 1 - The geographical setting of Motya with Sicily and within the Marsala Lagoon.

to the $8^{\text {th }}$ - first half of the $6^{\text {th }}$ centuries BC. Pits F.7057 and F.7012 were only studied in terms of macro-remains (seeds, fruits, and charred wood), while palynological analyses were also performed on samples from pit F.1112, one per each filling layer. These were collected sampled taking necessary precautions to avoid contamination. The choice of studying pollen and NPPs only in the disposal pit was motivated by F.1112 being comprised of multiple layers, therefore providing the possibility of obtaining a palynological sequence (which was impossible for the "sacred" contexts, represented by one stratigraphic unit each).

A total of $333 \mathrm{~L}$ and $41 \mathrm{~L}$ of sediment, respectively from pit F.1112 and the sacred contexts, were processed and analysed for macro-remains. Their separation was performed using the flotation technique, where the lighter

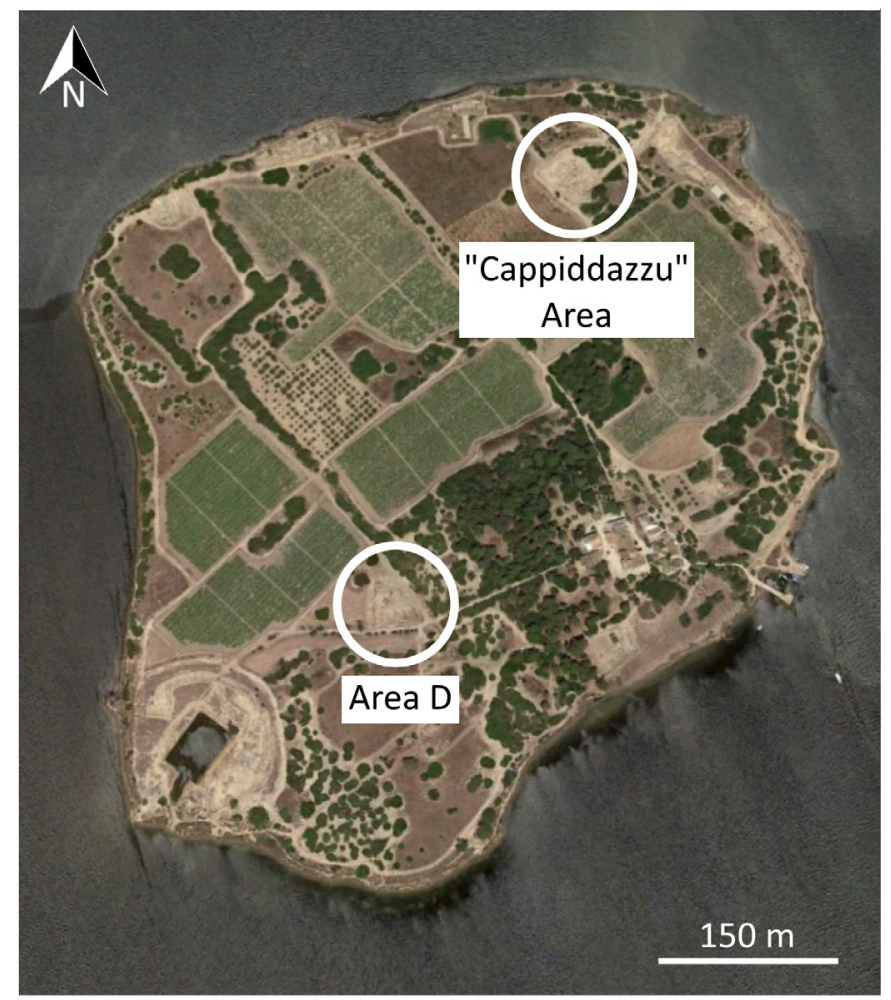

Fig. 2 - The excavation areas taken in consideration in this study: "Cappiddazzu" Area and Area D. remains were collected on a $250 \mu \mathrm{m}$ mesh. This process was followed by water-sieving of the heavy fraction on a 1 $\mathrm{mm}$ mesh. Once dry, the remains were separated using a stereomicroscope and identified based of a series of atlases (e.g. Neef et al., 2012). Charred wood fragments were observed in their diagnostic sections (transversal, tangential and radial) under a Normarski microscope. They were identified according to Schweingruber (1990). Botanical nomenclature follows Euro+Med (2006) for carpological remains, Schweingruber (1990) for anthracological remains and Greguss (1955) for Pinus taxa.

The samples collected for palynological analysis (a total of 4) were chemically treated following Faegri and Iversen (1989). This was followed by sieving of sample residues using a $10 \mu \mathrm{m}$ nylon sieve and treatment with ultrasound, to obtain clearer slides. Samples were weighted and a known amount of Lycopodium spores was added to each of them, allowing to estimate concentrations of pollen and NPPs, non-pollen palynomorphs (Stockmarr 1971). Pollen identification was carried out using atlases (Reille 19921998; Beug 2004).

Sampling, separation and identification of macroremains, and pollen treatment were performed by the author of this paper, while palynological analyses were partly carried out by Lucrezia Masci at Sapienza University of Rome.

\section{RESULTS}

A total of 96 taxa was identified within the carpological assemblages (Tab. 1). Out of these, 60 taxa were only found in the disposal pit, while 18 were found exclusively in the sacred contexts. Remains in pit F.1112 are mostly preserved through charring, while mineralization prevails in pits F.7057 and F.7012.

Overall, the assemblage of the disposal pit was richer in food plants, which were qualitatively and quantitatively less in the votive favissa (Fig. 3). These are represented by cereals (such as Hordeum vulgare L. - barley, Triticum turgidum subsp. dicoccon (Schrank) Thell. - emmer and Triticum aestivum/durum - bread wheats), pulses (the most numerous of which is Lathyrus oleraceus Lam. - green pea) and fruits (including Vitis vinifera L.- grapevine, and Punica granatum L. - pomegranate). Furthermore, the assemblage was abundant in weeds and ruderal plants, the most represented of which are Lolium temulentum L.- darnel, and two morphologies of Phalaris spp. - canary grass. In contrast, ruderal species - represented, among others, by Ajuga iva Schreb. (herb ivy), Echium parviflorum Moench (small-flowered viper's bugloss) and Anagallis arvensis L. (pimpernel) - prevailed in the votive deposits. Nonetheless, food plants such as Vitis vinifera, Ficus carica L. (Fig.) and Hordeum vulgare were also present.

In terms of anthracological remains, a total of 26 taxa was identified (Tab. 1). Out of these, 11 were only found in F.1112, and 6 were only retrieved in the votive pits. Taking into consideration all wood remains, Olea europaea L. (olive) was the most represented, with a total of 408 fragments attributed to this species. This was followed by Quercus evergreen (evergreen oaks; 240 fragments) - most common in the disposal pit, and Pistacia lentiscus L. (lentisk; 201 fragments), the prevalent species in F.7012. 
TABLE 1

List of carpological and anthracological taxa found in the secular and sacred deposits mentioned in the text.

\begin{tabular}{|c|c|c|c|c|c|c|c|c|c|c|c|}
\hline \multicolumn{2}{|c|}{ Taxon } & \multicolumn{2}{|c|}{ Secular Sacred } & \multirow{2}{*}{\multicolumn{2}{|c|}{$\begin{array}{r}\text { Taxon } \\
\text { REMAINS }\end{array}$}} & \multicolumn{2}{|c|}{ Secular Sacred } & \multicolumn{2}{|r|}{ Taxon } & \multicolumn{2}{|c|}{ Secular Sacred } \\
\hline \multicolumn{6}{|c|}{ CARPOLOGICAL REMAINS } & & & \multicolumn{4}{|c|}{ ANTHRACOLOGICAL REMAINS } \\
\hline \multicolumn{4}{|c|}{ CEREALS } & \multicolumn{4}{|c|}{ WEEDS AND RUDERALS } & 1 & Capparis spinosa & $\mathrm{X}$ & \\
\hline 1 & Avena cf. sativa & $\mathrm{X}$ & & 47 & Echium parviflorum & & $\mathrm{X}$ & 2 & Chamaerops humilis & $\mathrm{X}$ & \\
\hline 2 & Hordeum vulgare & $\mathrm{X}$ & $\mathrm{X}$ & 48 & Echium plantagineum & $\mathrm{X}$ & $\mathrm{X}$ & 3 & Cupressus sempervirens & $\mathrm{X}$ & \\
\hline 3 & Triticum monococcum & $\mathrm{X}$ & & 49 & Eleocharis palustris & $\mathrm{X}$ & $\mathrm{X}$ & 4 & cf. Cupressus sempervirens & $\mathrm{X}$ & \\
\hline 4 & Triticum aestivum/durum & $\mathrm{X}$ & & 50 & Euphorbia helioscopia & $\mathrm{X}$ & $\mathrm{X}$ & 5 & Erica arborea type & $\mathrm{X}$ & $\mathrm{X}$ \\
\hline 5 & Triticum turgidum subsp. dicoccon & $\mathrm{X}$ & $\mathrm{X}$ & 51 & Euphorbia peplus & & $\mathrm{X}$ & 6 & Erica multiflora type & $\mathrm{X}$ & \\
\hline 6 & Triticum sp. & $\mathrm{X}$ & & 52 & Fabaceae & $\mathrm{X}$ & & 7 & Erica arborea/muiltiflora & $\mathrm{X}$ & $\mathrm{X}$ \\
\hline 7 & Cereals indet. & $\mathrm{X}$ & $\mathrm{X}$ & 53 & Galactites tomentosa & & $\mathrm{X}$ & 8 & Faboideae & $\mathrm{X}$ & $\mathrm{X}$ \\
\hline \multicolumn{4}{|c|}{ PULSES } & 54 & Galium sp. & $\mathrm{X}$ & & 9 & Fraxinus sp. & $\mathrm{X}$ & $\mathrm{X}$ \\
\hline 8 & Lathyrus oleraceus & $\mathrm{X}$ & & 55 & Geranium cf. molle & $\mathrm{X}$ & & 10 & Juglans regia & & $\mathrm{X}$ \\
\hline 9 & Vicia ervilia & $\mathrm{X}$ & & 56 & Geranium/Medicago & $\mathrm{X}$ & & 11 & Juniperus sp. & $\mathrm{X}$ & \\
\hline 10 & Vicia faba & $\mathrm{X}$ & & 57 & Heliotropium europaeum & $\mathrm{X}$ & $\mathrm{X}$ & 12 & Maloideae & & $\mathrm{X}$ \\
\hline 11 & Vicia lens & $\mathrm{X}$ & & 58 & Hippocrepis sp. & $\mathrm{X}$ & & 13 & Olea europaea & $\mathrm{X}$ & $\mathrm{X}$ \\
\hline 12 & Vicia/Lathyrus & $\mathrm{X}$ & & 59 & Hordeum murinum & $\mathrm{X}$ & & 14 & Pinus sylvestris-montana group & $\mathrm{X}$ & \\
\hline 13 & Pulses indet. & $\mathrm{X}$ & & 60 & Lolium multiflorum/perenne & $\mathrm{X}$ & & 15 & Pinus cf. sylvestris-montana group & $\mathrm{X}$ & \\
\hline \multicolumn{4}{|c|}{ FRUITS } & 61 & Lolium temulentum & $\mathrm{X}$ & & 16 & cf. Pinus sp. & & $\mathrm{X}$ \\
\hline 14 & Crataegus monogyna & $\mathrm{X}$ & & 62 & Malva cf. sylvestris & $\mathrm{X}$ & & 17 & Pistacia lentiscus & $\mathrm{X}$ & $\mathrm{X}$ \\
\hline 15 & Crataegus sp. & $\mathrm{X}$ & & 63 & Malva cf. nicaeensis & $\mathrm{X}$ & & 18 & Pistacia terebinthus & $\mathrm{X}$ & \\
\hline 16 & Ficus carica & $\mathrm{X}$ & $\mathrm{X}$ & 64 & Malva sp. & $\mathrm{X}$ & $\mathrm{X}$ & 19 & Pistacia sp. & $\mathrm{X}$ & $\mathrm{X}$ \\
\hline 17 & Olea europaea & $\mathrm{X}$ & & 65 & Medicago polymorpha & & $\mathrm{X}$ & 20 & Prunus sp. & & $\mathrm{X}$ \\
\hline 18 & Pinus pinea & $\mathrm{X}$ & & 66 & Medicago cf. truncatula & & $\mathrm{X}$ & 21 & Quercus evergreen & $\mathrm{X}$ & $\mathrm{X}$ \\
\hline 19 & Pinus cf. pinea & $\mathrm{X}$ & & 67 & Medicago sp. & $\mathrm{X}$ & & 22 & Quercus sp. & $\mathrm{X}$ & \\
\hline 20 & Punica granatum & $\mathrm{X}$ & & 68 & cf. Medicago & $\mathrm{X}$ & & 23 & Rhamnus/Phillyrea & $\mathrm{X}$ & $\mathrm{X}$ \\
\hline 21 & Vitis vinifera & $\mathrm{X}$ & & 69 & Mercurialis annua & & $\mathrm{X}$ & 24 & Rosoideae & $\mathrm{X}$ & \\
\hline \multicolumn{4}{|c|}{ OIL PLANTS } & 70 & Microrrhinum minus & $\mathrm{X}$ & & 25 & Vitis vinifera & & $\mathrm{X}$ \\
\hline 22 & cf. Linum usitatissimum & $\mathrm{X}$ & & 71 & Misopates sp. & $\mathrm{X}$ & & 26 & Conifer & & $\mathrm{X}$ \\
\hline \multicolumn{4}{|c|}{ ORNAMENTAL PLANTS } & 72 & Persicaria amphibia & $\mathrm{X}$ & & & & & \\
\hline 23 & cf. Cupressus sempervirens & & $\mathrm{X}$ & 73 & Phalaris cf. minor & $\mathrm{X}$ & & & & & \\
\hline \multicolumn{4}{|c|}{ WEEDS AND RUDERALS } & 74 & Phalaris spp. & $\mathrm{X}$ & $\mathrm{X}$ & & & & \\
\hline 24 & Ajuga iva & & $\mathrm{X}$ & 75 & Plantaginaceae & $\mathrm{X}$ & & & & & \\
\hline 25 & Ammi majus & $\mathrm{X}$ & & 76 & Poaceae & $\mathrm{X}$ & & & & & \\
\hline 26 & Anagallis arvensis & $\mathrm{X}$ & $\mathrm{X}$ & 77 & Polygonum sp. & $\mathrm{X}$ & & & & & \\
\hline 27 & Apiaceae & & $\mathrm{X}$ & 78 & Polygonaceae & $\mathrm{X}$ & & & & & \\
\hline 28 & Artemisia arborescens & $\mathrm{X}$ & & 79 & Portulaca oleracea & $\mathrm{X}$ & & & & & \\
\hline 29 & Astragalus cf. böeticus & & $\mathrm{X}$ & 80 & Potentilla sp. & $\mathrm{X}$ & & & & & \\
\hline 30 & Avena fatua & $\mathrm{X}$ & & 81 & Ranunculus sp. & $\mathrm{X}$ & & & & & \\
\hline 31 & Avena sp. & $\mathrm{X}$ & & 82 & Raphanus raphanistrum & $\mathrm{X}$ & & & & & \\
\hline 32 & Briza maxima & $\mathrm{X}$ & & 83 & Rumex sp. & $\mathrm{X}$ & & & & & \\
\hline 33 & Borago officinalis & & $\mathrm{X}$ & 84 & Scirpoides holoschoenus & $\mathrm{X}$ & & & & & \\
\hline 34 & Brassicaceae & & $\mathrm{X}$ & 85 & Sherardia arvensis & $\mathrm{X}$ & & & & & \\
\hline 35 & Brassicaceae small & & $\mathrm{X}$ & 86 & Silene cf. vulgaris & $\mathrm{X}$ & & & & & \\
\hline 36 & Bromus sp. & $\mathrm{X}$ & & 87 & cf. Silene sp. & $\mathrm{X}$ & & & & & \\
\hline 38 & Carex sp. & $\mathrm{X}$ & & 88 & Sisymbrium cf. irio & & $\mathrm{X}$ & & & & \\
\hline 39 & Caryophyllaceae & $\mathrm{X}$ & $\mathrm{X}$ & 89 & cf. Spergula arvensis & $\mathrm{X}$ & & & & & \\
\hline 40 & Cerastium cf.glomeratum & $\mathrm{X}$ & & 90 & Thymelaea cf. hirsuta & & $\mathrm{X}$ & & & & \\
\hline 41 & Chenopodium album & $\mathrm{X}$ & & 91 & Urtica membranacea & $\mathrm{X}$ & $\mathrm{X}$ & & & & \\
\hline 42 & Chenopodiastrum murale & $\mathrm{X}$ & $\mathrm{X}$ & 92 & Urtica urens & $\mathrm{X}$ & $\mathrm{X}$ & & & & \\
\hline 43 & Cichorium cf. intybus & & $\mathrm{X}$ & 93 & Urtica sp. & $\mathrm{X}$ & & & & & \\
\hline 44 & Coronilla sp. & $\mathrm{X}$ & & 94 & Verbena officinalis & & $\mathrm{X}$ & & & & \\
\hline 45 & Cyperaceae & $\mathrm{X}$ & $\mathrm{X}$ & 95 & Veronica sp. & $\mathrm{X}$ & & & & & \\
\hline 46 & Dittrichia graveolens & & $\mathrm{X}$ & 96 & Vulpia sp. & $\mathrm{X}$ & & & & & \\
\hline
\end{tabular}




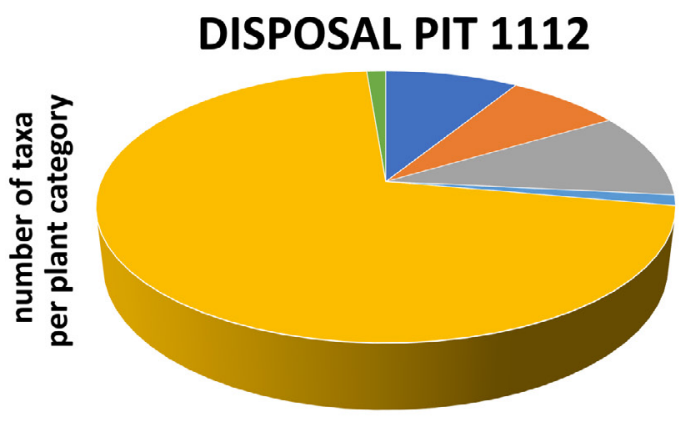

\section{VOTIVE PITS 7057 AND 7012}
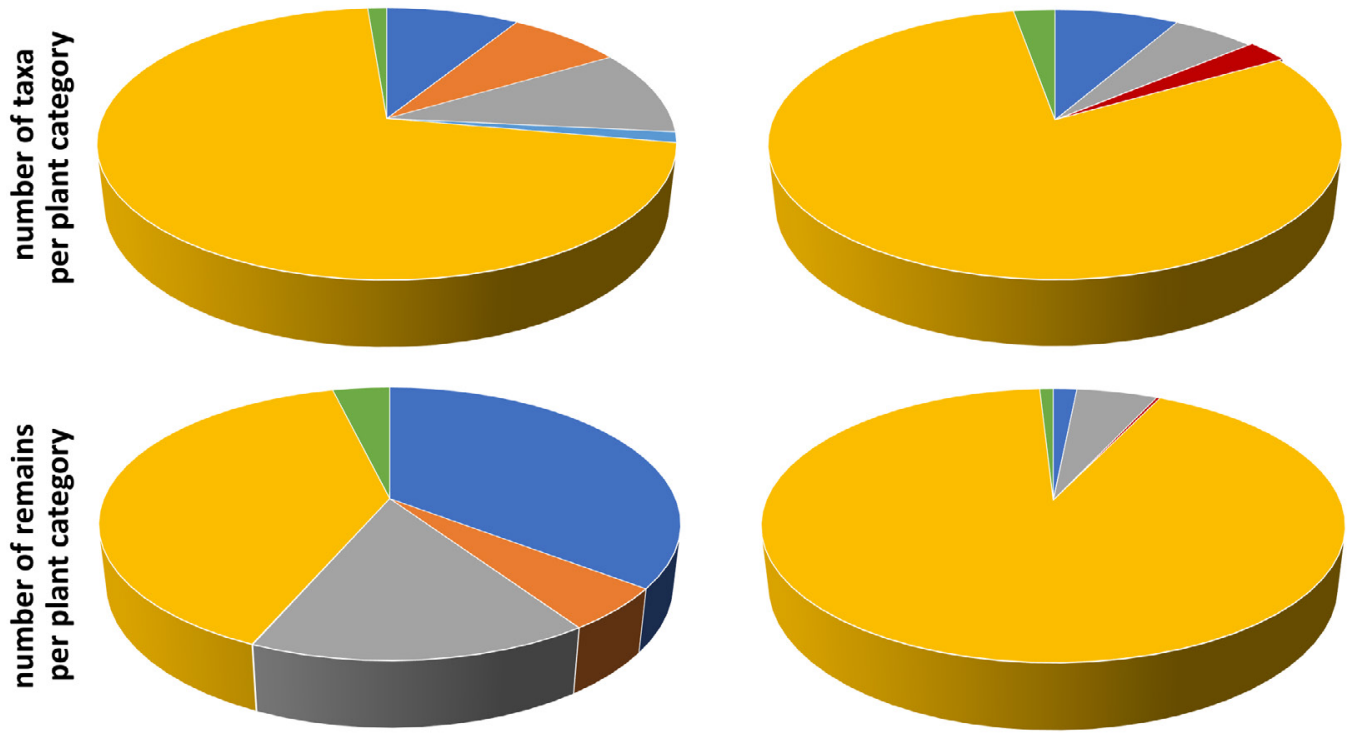

cereals $\quad$ fruits
pulses ornamental plants

oil plants

weeds/ruderals
Fig. 3 - Pie charts representing the number of taxa and number of remains per plant category, for both the disposal pit and the votive deposits.
46 pollen taxa were identified in the samples from the disposal pit. Palynological spectra are characterized by scarce arboreal pollen. This consists of evergreen (Quercus ilex-type, including all evergreen Mediterranean oak species except Quercus suber, and Pinus) and deciduous elements (deciduous and semi-deciduous oaks, and Alnus), taxa typical of the Mediterranean maquis (Ericaceae, Juniperus, Pistacia) and evidence of locally cultivated tree taxa (Juglans and Vitis).

Herbaceous taxa are present in higher percentages. Amongst these, the most abundant are Asteraceae Asteroideae, followed by Poaceae and Asteraceae Cichorieae. Numerous cultivated and ruderal plants are included in this category, such as cereals (Avena/Triticum group and Hordeum group), Plantago lanceolata type, Plantago undiff., Urtica, Brassicaceae, Fabaceae and Rumex.

Finally, non-pollen palynomorphs (NPPs) are represented by Glomus, Pseudoschizaea, Tecaphora, Turbellaria and Rotifera eggs. Glomus and Pseudoschizaea are interpreted as indicators of erosion in lacustrine records (Sadori, 2018).

\section{DISCUSSION}

The archaeobotanical analysis of different contexts at Motya allows to gather information concerning secular and sacred aspects of Phoenician's life. Furthermore, it makes it possible to reconstruct the past cultural landscape of the site.

Concerning the ritual sphere (discussed more in detail in Moricca et al., 2020), the retrieval of charred cereal caryopses, grape pips and a mineralized fig achene in the votive deposits corroborates the archaeological hypothesis that meals accompanied animal sacrifices (Moricca et al., 2020). Interesting is the presence of 14 spontaneous taxa with officinal properties, used in traditional medicine to cure a series of pathologies. These mineralized seeds/fruits include Borago officinalis L. (borage) and Euphorbia peplus L. (petty spurge), plants that are used, among others, for the treatment of disorders of the respiratory system and the urinary tract (Pieszak et al., 2012), and Galactites tomentosus Moench (purple milk thistle) employed as a remedy for cardiovascular diseases (González-Tejero et al., 2008). These records may be associated to the cult of the god Melqart, to whom the temple adjacent to the deposit is dedicated, who at Motya includes some of the salvific properties of Eshmun, the Phoenician healer-god.

Another peculiar aspect is given by the fact that over $50 \%$ of the taxa in the archaeobotanical assemblage of votive pit F.7057 are toxic to livestock. These include Anagallis arvensis, some members of the Boraginaceae and Euphorbiaceae families, and Dittrichia graveolens (L.) Greuter. Their ingestion has been shown to cause acute liver failure, lethargy, constipation, and hemolytic anemia, sometimes leading to death (Moricca et al., 2020). These plants have been interpreted as being fed to animals to sedate them before sacrifice. A similar hypothesis was advanced to explain the high concentrations of Echium pollen in dung layers in the Uan Afuda cave (Libya; Mercuri, 2008). Nonetheless, considering that these are all ruderal species, it is possible that they simply represent plants that grew spontaneously near the Temple of Melqart/Herakles when the votive pit was created and attest human activities.

With reference to secular aspects (discussed in detail in Moricca et al., 2021a), diet of the Phoenician inhabitants of the island can be reconstructed through the study of the 
carpological assemblage of the disposal pit. We now know that, in terms of plant components, it was comprised of cereals, pulses and fruits. Among cereals, hulled barley and naked wheats prevail, coherently with data gathered from the Iron Age Western Sicilian sites of Selinunte and Monte Polizzo (Stika et al. 2008). Several pulse taxa were also retrieved. While green peas, lentils (Vicia lens (L.) Coss. \& Germ.) and broad beans (Vicia faba L.) were probably destined for human consumption, other vetches could have been used as fodder along with hulled barley, which is less palatable than its naked counterpart or naked wheats. Fruits were also a conspicuous part of the food assemblage. Amongst these, grape was the most abundant and was retrieved in the form of grape pips and pedicels. The pips were studied morphologically and identified as belonging to different varieties of Vitis vinifera subsp. vinifera, the domesticated subspecies (Moricca et al., 2021b). The proportion of pips to pedicels indicates winemaking (Margaritis \& Jones, 2006). This is also confirmed by the presence of tartaric acid in the dental calculus of $6^{\text {th }}$ century BC inhabitants of Motya (D'Agostino et al., 2020).

The fruit assemblage of the disposal pit is also characterized by taxa associated to Phoenician expansion and trades. Other than grapevine and olive, associated respectively to viticulture and oil production - which are characteristic elements of Phoenician colonization (Buxò, 2008), pomegranate exocarp fragments and Mediterranean stone pine (Pinus pinea L.) remains were identified. Whereas pomegranate is believed to have been brought from the Levant (Nigro \& Spagnoli, 2018), the interpretation of the Mediterranean stone pine is more complex. Due to the extremely low genetic variability, the origins of Pinus pinea have long been subject of debates. Nonetheless, it appears that the retrieval of Mediterranean stone pine at Motya could testify contacts with the Iberian Peninsula, as hypothesized for the finds in Punic Carthage (Van Zeist et al., 2001). Peculiar is also the presence of Cupressus sempervirens L. (cypress), an ornamental plant often associated to the funerary world. A cypress twig was found in votive pit 7057, while its wood was present in the disposal pit. It is hypothesized that Phoenicians and Etruscans favored the spread of this plant, although genetic and paleobotanic data suggest that it may be native to Italy (Bagnoli et al., 2009).

Imported species at Motya, found in the anthracological assemblage, also include Juglans regia L. (walnut) and Pinus sylvestris/montana (mountain pine). Juglans pollen is also present in soil samples from F.1112 and appears in Sicilian pollen spectra in the $8^{\text {th }}-7^{\text {th }}$ centuries BC (Sadori, 2013). It is possible that Phoenicians favored its spread, perhaps for its fruits and good quality of timber. The group Pinus sylvestris/ montana, based on wood features, is comprised of montane pines, only one of which (Pinus nigra Arnold subsp. laricio Palib. ex Maire) currently grows in Sicily, on Mount Etna. It is therefore possible that also this species was either brought from Mount Etna or imported from the Balkans or the Phoenician territories in Cyprus, northern Africa or the southern coast of Spain. Pine timber is known to be used for ship making, and the retrieval of only one fragment could also lead to the hypothesis that it belonged to one of the ships that arrived to Motya (Moricca et al., 2021a).

The archaeobotanical assemblage of the disposal pit also provides interesting information concerning agricultural practices (thoroughly discussed in Moricca et al., 2021a). Firstly, the presence of chaff fragments and different-sized weeds, suggests that these derive from different stages of processing (Stevens, 2003). Taking in consideration the ratios of "big" weeds to "small" weeds, and of weeds to cereal caryopses, it is possible to advance the hypothesis that processing was performed daily, after storage. Furthermore, the retrieval of cereal pollen in samples from F.1112 suggests that threshing, if not even cultivation, was carried out on-site, close to the studied deposit.

In terms of land exploitation, it is reasonable to believe that grapevine was also cultivated locally, as suggested by the presence of Vitis vinifera wood in the antracological assemblage of votive pit 7057 and in the pollen spectra. Similarly, the abundance of Olea europaea wood in both contexts indicates local growing. This data is coherent with the land-exploitation model constructed for Motya based on demographic studies (Nigro, 2017).

Finally, the analyses here presented, allow to reconstruct past environment, highlighting some differences with the present-day vegetation of Western Sicily (Moricca et al., 2021a). Through palynological analyses, the environment can be described as open, with little forest cover, characterized by complex anthropogenic activities. These are evidenced by high percentages of Asteroideae, Cichorieae, Cerealia, Poaceae, Plantago and Urtica pollen, but also of NPPs such as Glomus and Pseudoschizaea. Anthracological data help to complete the picture of the local environment, characterized by the presence of evergreen oaks, olive trees, and numerous shrubs, such as Pistacia lentiscus, Faboideae, Rhamnus/Phyllirea, Erica cf. arborea L. (tree heath), Erica cf. multiflora L. (Mediterranean heath) and Juniperus sp. (juniper). It is interesting to notice how tree heath and juniper, which is also present in the pollen spectra, are no longer found in Western Sicily. This could be due to a series of factors. The first one concerns the fact that juniper is less performant after a fire than other plants of the macchia (e.g. heaths and lentisk), which, in contrast, sprout more easily. Amongst heaths, Erica arborea requires a deeper and more advanced soil than E. multiflora, leading to the hypothesis that aridification and land over-exploitation could have played a key role in its disappearance.

Another difference compared to the modern environment is comprised by the find of Mediterranean pines' (Pinus pinea/pinaster) pollen in percentages that suggest local growing. While it is impossible to distinguish between Pinus pinea and Pinus pinaster Aiton based on pollen morphology detected at the transmitted light microscope, none of these species currently grow in Western Sicily. Pinus pinaster is believed to be autochtonous in the southernmost island of Sicily, Pantelleria. It is anyway reasonable to believe that the presence of the pine pollen grains is correlated to the finds of Pinus pinea in the carpological assemblage and was imported from the Iberian Peninsula.

\section{CONCLUSIONS}

In spite of Phoenicians having expanded and settled along the coasts of the Mediterranean basin, from the Levant towards the west, surpassing the Strait of Gibraltar, they have not yet been thoroughly investigated from an 
archaeobotanical point of view. Phoenician plant records are, in fact, still fragmented.

The study here presented contributes to the understanding of human-environment interactions of Phoenicians in the central Mediterranean, both in terms of sacred and secular aspects. It gathers the results deriving from the first systematic archaeobotanical study performed at the Phoenician site of Motya. The potential of multidisciplinary archaeobotanical analyses is highlighted, through the study of two different contexts. A broad picture was only possible thanks to the combination of the study of macro- and micro-remains.

Concerning the ritual sphere, the carpological remains of cereals, grapes and figs have allowed to confirm the archaeological hypothesis that ritual meals accompanied animal sacrifices. Archaeobotany also attests to the offering of flowers, ornamental and prestigious plants. A high concentration of plants with medicinal properties may be linked to Melqart/Herakles, the titular deity of the studied temple. An interesting aspect is given by the presence of numerous taxa toxic to livestock. The find of such plants could indicate intentional poisoning, aimed at sedating the animals before sacrificing them, proposing a novel interpretation for the ritual practices carried out on the island. Nonetheless, these plants could simply represent ruderals that grew nearby the studied deposit at the time in which it was created.

In terms of secular aspects, human diet of the Phoenicians at Motya was comprised of cereals (mostly naked wheats), pulses and fruits. As suggested by pollen evidence and previous demographic studies, cereals were likely cultivated on-site. Remains of different sized weeds and chaff in the carpological assemblage, as well as their amount in relation to grains, suggest that processing was carried out daily after storage. As far as fruits are concerned, morphometry has allowed to characterize the grape pips found as Motya as belonging to domesticated varieties. Other fruits associated to Phoenician expansion were also found. These include pomegranate and the Mediterranean stone pine, probably imported respectively from east and west.

Anthracological remains from both the studied contexts give indications on the choice of timber, showing a preference for local taxa. While in the disposal pit evergreen oaks represent the prevalent taxon, Olea europaea, characterized by a slow growth rate, was preferred in the sacred context. Nonetheless, rarer taxa are also attested. These include walnut and mountain pine.

Past environment is inferred by anthracological and palynological evidence. Palynology allows for the depiction of a strongly anthropized Mediterranean landscape, with little to no forest cover. Anthracology helps to complete the local environmental picture, with findings of Pistacia lentiscus, Olea europaea, Erica multiflora type, Erica arborea type, Juniperus sp. and evergreen oaks.

Furthermore, it was possible to identify some changes that occurred in time in the vegetation of Western Sicily. Erica arborea and Juniperus sp. are absent in the present-day flora of the Marsala lagoon. Their complete disappearance could be due to burning and land overexploitation associated to aridification.

While this study has allowed the investigation of many key aspects of the human-plant relationship of Phoenicians at Motya, a lot can still be unraveled. Future studies could focus on the analysis and comparison of plant assemblages from different contexts which have not yet been brought to light, allowing researchers to gather a broader view on the investigated issue. The potential of pollen records should not be discarded, as they have been proven to provide information complementary to those obtained through the study of macro-remains. Furthermore, the analysis of a continuous stratigraphic sequence would allow researchers to obtain an image of the environment changing through the course of time.

In conclusion, the present study has facilitated the successful description of the interactions of Phoenicians and plants at the site of Motya during the Iron Age, also depicting an image of the past environment. This has greatly contributed to filling a gap in the knowledge of this enigmatic set of populations, providing new perspectives for future studies.

\section{ACKNOWLEDGEMENTS}

This article is a product of the PeMSea Project [Prin2017] (A.3 Food traditions \& food plants) funded by the Italian Ministry of Scientific Research and University. The Archaeological Expedition to Motya of Sapienza University of Rome operates in cooperation and under the aegis of the Regional Superintendence of Trapani (Sicily), and thanks to the hospitality and collaboration of G. Whitaker Foundation, Palermo. Archaeological investigations are funded by Sapienza University of Rome Special Grant for Great Excavations, and the Ministry of University and Scientific Research (PRIN 2017) Excavations at Motya are directed by Prof. Lorenzo Nigro. On-field excavations in the 'Cappiddazzu' area were directed by Pierpaolo Bigini and Sharon Sabatini, while the ones in Area D by Federico Cappella.

The author is grateful to her supervisors, Prof. Lorenzo Nigro and Prof. Laura Sadori. She is also thankful to Lucrezia Masci for carrying out palynological analyses.

\section{REFERENCES}

Alhaique F. (2012) - Resti faunistici della favissa F.2950 (Mozia). In: Nigro L., Spagnoli F. (eds.). [Alle sorgenti del Kothon. Il rito a Mozia nell'Area sacra di Baal 'Addir Poseidon. Lo scavo dei pozzi sacri nel settore C Sud-Ovest (2006-2011)] At the sources of Kothon. The rite in Motya in the sacred area of Baal 'Addir - Poseidon. The excavation of the sacred wells in sector C SouthWest (2006-2011)]. Quaderni di archeologia fenicio-punica/CM02. Missione Archeologica a Mozia, 33. Italian.

Bagnoli F., Vendramin G.G., Buonamici A., Doulis G., Gonzalez Martinez S.C., La Porta N., Magri D., Raddi P., Sebastiani F. \& Fineschi S. (2009) - Is Cupressus sempervirens native in Italy? An answer from genetic and palaeobotanical data. Mol. Ecol., 18(10), 2276-2286.

Bernabale M., Nigro L., Montanari D., Niveau-de-Villedary A.M. \& De Vito C. (2019) - Microstructure and chemical composition of a Sardinian bronze axe of the Iron Age from Motya (Sicily, Italy). Mat. Character., 158, 109957.

Beug H.J. (2004) - Guideline for pollen determination for Central Europe and neighboring areas Leitfaden der Pollenbestimmung für Mitteleuropa und angrenzende Gebiete. Verlag Dr. Friedrich Pfeil, Munich. German

Buxó R. (2008) - The agricultural consequences of colonial contacts on the Iberian Peninsula in the first millennium B. C. Veg. Hist. Archaeobot., 17(1), 145-154.

D’Agostino A., Canini A., Di Marco G., Nigro L., Spagnoli F. \& Gismondi A. (2020) - Investigating Plant Micro-Remains Embedded in Dental Calculus of the Phoenician Inhabitants of Motya (Sicily, Italy). Plants, 9(10), 1395.

Euro+Med PlantBase - the information resource for EuroMediterranean plant diversity. 2006-. Berlin: Botanic Garden and Botanical Museum Berlin-Dahlem. http://ww2.bgbm.org/ EuroPlusMed/. Accessed 20 March 2021.

Fabrizi L., Nigro L., Spagnoli F., Ballirano P. \& De Vito C. (2020) The Red Slip Ware from Motya (Sicily, Italy): A multi-analytical 
approach for determining the production technology and the nature of the raw materials. Ceram. Int., 46(2), 1640-1651.

Faegri K. \& Iversen J. (1989) - Textbook of pollen analysis. John Wiley.

González-Tejero M.R., Casares-Porcel M., Sánchez- Rojas C.P., Ramiro-Gutiérrez J.M., Molero-Mesa J., Pieroni A., Giusti M.E. (2008) - Medicinal Plants in the Mediterranean Area: Synthesis of the Results of the Project Rubia. J Ethnopharmacol., 116(2), 341-357.

Greguss P. (1955) - Identification of living gymnosperms on the basis of xylotomy. Akadémiai Kiadó.

Margaritis E. \& Jones M. (2006) - Beyond cereals: crop processing and Vitis vinifera L. Ethnography, experiment and charred grape remains from Hellenistic Greece. J. Archaeol. Sci., 33(6), 784-805.

Mercuri A.M. (2008) - Plant exploitation and ethnopalynological evidence from the Wadi Teshuinat area (Tadrart Acacus, Libyan Sahara). J. Archaeol. Sci., 35(6), 1619-1642.

Moricca C., Bouby L., Bonhomme V., Ivorra S., Pérez-Jordà G. Nigro L., Spagnoli F., Peña-Chocarro L., van Dommelen P. \& Sadori, L. (2021b) - J. Archaeol. Sci. Rep., 32, 102991. https://doi. org/10.1016/j.jasrep.2021.102991

Moricca C., Nigro L., Masci L., Pasta S., Cappella F., Spagnoli F. \& Sadori L. (2021a) - Cultural landscape and plant use at the Phoenician Motya (Western Sicily, Italy) inferred by a disposal pit. Veg. Hist. Archaeobot. https://doi.org/10.1007/s00334-021-00834-1

Moricca C., Nigro L., Spagnoli F., Sabatini S. \& Sadori, L. (2020) Plant Assemblage of the Phoenician Sacrificial Pit by the Temple of Melqart/Herakles (Motya, Sicily, Italy). Env. Archaeol., 1-13.

Neef R., Cappers R. T. \& Bekker, R. M. (2012) - Digital atlas of economic plants in archaeology (Vol. 17). Barkhuis, Groningen.

Nigro L. (2019) - L'acqua di Mozia: captazione, consumo e significati in ambito civile e religioso. In: Bouffier S., Belvedere O., Vassallo S. (Eds.). Gérer l'eau en Méditerranée au premier millénnaire avant J. -C., 137-153. Italian.

Nigro L. (2017) - Motya IV: building up a West Phoenician colony. In: Nigro L, Spagnoli F (Eds.) Landing on 18 Motya. The earliest Phoenician settlement of the 8th century BC and the creation of a West Phoenician cultural 19 identity in the excavations of Sapienza University of Rome - 2012-2016. Missione Archeologica a Mozia, 104-110.
Nigro L. \& Spagnoli F. (2018) - Pomegranate (Punica granatum L.) from Motya and its deepest oriental roots. Vicino Oriente., 22, 49-90.

Nigro L. \& Spagnoli F. (2017) - Landing on Motya. The earliest Phoenician settlement of the $8^{\text {th }}$ century $\mathrm{BC}$ and the creation of a West Phoenician cultural identity in the excavations of Rome «La Sapienza» University - 2012-2016. Stratigraphy, architecture, and finds. Quaderni di Archeologia Fenicio-Punica/Colour Monograph 04. Missione archeologica a Mozia.

Pieszak M., Mikolajczak P.L. \& Manikowska K. (2012) - Borage (Borago officinalis L.) - a Valuable Medicinal Plant Used in Herbal Medicine." Herba Pol., 58(4), 95-103.

Reille M. (1992-1998) - [Pollen and spores from Europe and North Africa]. Pollen et spores d'Europe et 12 d'Afrique du Nord. Laboratoire de botanique historique et palynologie, Marseille. French.

Sadori L. (2018) - The Lateglacial and Holocene vegetation and climate history of Lago di Mezzano (central 23 Italy). Quaternary Sci. Rev., 202, 30-44.

Sadori L. (2013) - Southern Europe. In: Elias S.A. (Ed.). The Encyclopedia of Quaternary Science., 4, 179-188.

Schweingruber F.H. (1990) - Anatomy of European woods. Paul Haupt Berne and Stuttgart Publishers.

Stevens C.J. (2003) - An investigation of agricultural consumption and production models for prehistoric and Roman Britain. Env. Archaeol., 8(1), 61-76.

Stockmarr J. (1971) - Tablets with spores used in absolute pollen analysis. Pollen Spores., 13, 615-621.

Terranova F., Accorsi C.A., Mazzanti M., Mercuri A.M., Torri P. Manicardi E., Montecchi M.C., Olmi L., Rindaldi R., Valenti A., Benassi F., Pensabene P. \& Tusa S. (2009) - [Indagini archeopalinologiche in Sicilia a Taormina, Piazza Armerina e Mozia] Archaeopalynological analyses in Sicily in Taormina, Piazza Armerina and Motya. In: III Convegno Internazionale 'La materia e i segni della storia'. Regione Sicilia, 184-194. Italian.

Van Zeist W., Bottema S. \& Van der Veen M. (2001) - Diet and vegetation at ancient Carthage: the archaeobotanical evidence. Groningen Institute of Archaeology. 